\title{
Miranda
}

Revue pluridisciplinaire du monde anglophone /

Multidisciplinary peer-reviewed journal on the English-

speaking world

$12 \mid 2016$

Mapping gender. Old images ; new figures

\section{Françoise Král, Social Invisibility and Diasporas in Anglophone Literature and Culture. The Fractal Gaze}

\section{Mathilde Rogez}

URL: http://journals.openedition.org/miranda/7842

DOI: $10.4000 /$ miranda.7842

ISSN: 2108-6559

Publisher

Université Toulouse - Jean Jaurès

\section{Electronic reference}

Mathilde Rogez, "Françoise Král, Social Invisibility and Diasporas in Anglophone Literature and Culture. The Fractal Gaze", Miranda [Online], 12 | 2016, Online since 26 February 2016, connection on 16 February 2021. URL: http://journals.openedition.org/miranda/7842 ; DOI: https://doi.org/10.4000/ miranda.7842

This text was automatically generated on 16 February 2021

\section{(c) $(1)$}

Miranda is licensed under a Creative Commons Attribution-NonCommercial-NoDerivatives 4.0 International License. 


\title{
Françoise Král, Social Invisibility and Diasporas in Anglophone Literature and Culture. The Fractal Gaze
}

\author{
Mathilde Rogez
}

\section{REFERENCES}

Françoise Král, Social Invisibility and Diasporas in Anglophone Literature and Culture. The Fractal Gaze (Basingstoke: Palgrave Macmillan, 2014), 248 p, ISBN 978-1-137-40138-0

1 At a time when so many migrants are dying off the coasts of Europe, unmourned, as they tried to find a place where they could live or survive away from political oppression in Syria or Eritrea, Françoise Král's attempt to put back in the limelight those people whose lives "have been declared ungrievable" (2) and others who, maybe less dramatically but no more tolerably, remain or become socially and politically invisible, must be praised for its very ethical necessity. Sadly, it has not lost its timeliness since its publication last year. Král relies, among others, on the works of Judith Butler (Precarious Life: The Powers of Mourning and Violence [London and New York: Verso, 2004]), Guillaume Le Blanc (L'Invisibilité sociale [Paris : Presses Universitaires de France, 2009]) and Emmanuel Renault (Mépris social: Ethique et politique de la reconnaissance [Bègles: Edition du Passant, 2000]), but the scope of her theoretical background is much vaster, even impressive, ranging from Sartre to Deleuze and Guattari, Debord, Spivak, Appadurai and Bhabha or Bauman, and from philosophers, sociologists, anthropologists or geographers, based in America, France or India. The author is indeed very careful to point out the methodological difficulties in analysing a topic which is by definition little documented, and advocates a combination of disciplines, which the humanities actually allow for, and she can be praised for taking pains to delineate possible methodologies in both the introduction and the first chapter. 
2 The book thus sets out to trace the paradox of the social and political invisibility which is imposed on some people, at a time of hypervisibility or omnivisibility, or of transparency (Gianni Vattimo, The Transparent Society [Oxford: Blackwell, 1989]), in particular with the development of new media, a paradox which is exposed very clearly in the introduction. The author focuses more particularly on the workings of invisibility regarding diasporians, who form the majority of people relegated to the invisible margins of society, particularly in today's world of flows of migrations and global capitalism, and besides offer an interesting prism through which to examine the ins and outs of visibility, as they can just as well be made to stand out very conspicuously at other times, sometimes actually only to be played against other groups and unwittingly serve other political agendas. The book indeed offers to reflect as well on the temporality of invisibility and the issues of memory and the archive. It is to be said, however, that the word "diasporians" is used by Král rather loosely at times, as in the introduction she includes in her examples populations displaced within the same country, for instance in India. Sometimes indeed there are slippages between diasporians and invisible people in general, which is not necessarily a drawback as it makes for interesting developments on global inequalities for instance, but one could at times have wished for either stricter definitions (as for the word "neo-diasporians" on page 148), or clearer points of comparisons, where the author could underline more what exactly diasporic artists bring to their approach of invisibility that others do or may not. Some comparisons are announced, but are not always made, as with the recurring allusion to Danny Boyle's Slumdog Millionaire, which is actually never developed.

3 The book is divided into three parts composed of two chapters each, although those are not entirely balanced, as chapters and parts tend to become shorter, and gradually lack concluding remarks (chapters 4 and 5) which elsewhere generally provide very helpful summaries and transitions. Part I mostly deals with the theoretical aspects of what Král calls "Invisibility studies", but manages to lay out the issues of economic and social invisibility very clearly, as well as their relations to space, which needs to be rematerialised to show the tensions and frictions at work even in our globalised world. Král manages to do so by skilfully using illustrative examples mostly drawn from literature, and this is where she is probably at her best, for instance providing an illuminating analysis of Salman Rushdie's Satanic Verses which beautifully weaves together the text of the novel, the theoretical background, and her own commentary, in very balanced and elegantly written paragraphs.

4 Part II focuses more on the visual arts (photography, installations and films, in particular those of Mona Hatoum, Gurinder Chadha and Mira Nair) and the way they question invisibility, particularly in their focus on the body, another motif which is introduced in that part of the book. Král shows that through their works and more specifically their representations of traces of the invisible body of the other, these artists try to avoid the pitfalls of overexposure and essentialisation, or exploitation, and instead question the previous scopophilia of the West and to displace the gaze of the viewer ("dysgazing", 75), who is thus asked to take an active part in the creation of the work of art. Král expands the scope of her analysis to include anthropological photographs and human zoos, whose motives are laid bare by a comparison with recent artistic works which are usefully reproduced in the book. One could however regret here that not that many works are actually discussed, some artists being only 
mentioned, sometimes without their full name and with no notes attached, so that their identity, status and work remain rather mysterious for the uninitiated reader, which also occurs with some apparently well-known films which are nevertheless not fully referenced (Paurab aur Paschim, 113-14). One could not help wondering if the "Bailey" quoted on page 83 may not have been South African artist Brett Bailey, not a diasporic artist strictly speaking then but whose work nevertheless has triggered much debate as he worked with migrants in Europe and black people and migrants in South Africa in his "Exhibit A" and "Exhibit B" to displace the gaze of Europeans and unsettle white South Africans, themselves migrants of a kind. A comparison of his rather ambiguous or at least disputed position with that of truly diasporic artists, if one may say so, would have been extremely rewarding, and one is left a little frustrated thinking what Král, with her mastery of theory and her analytical insight, would have been able to suggest on that topic, as she elsewhere in the chapter interestingly takes into consideration issues such as the interaction of the local and the global and the impact of the conditions of the production of the works of art on their nature and reception.

Part III moves on to the workings of invisibility in the hypermodern city, as it relies more and more on migrants and displaced people, moving from the country or from other countries, and uses again a little more theory, and literature. An interesting analysis of Sam Selvon leads to a reassessment of the notion of home and the appearance of "the motif of luggage" (147), which could prove seminal indeed if one thinks of other works by diasporians, for instance Taiye Selasi's novel Ghana Must Go (New York: Penguin, 2013) or what some artists have done in South Africa in video installations focussing on the bags carried by migrants from Nigeria or Zimbabwe. It is in this section that the subtitle to the book, "the fractal gaze", is explained: Král uses the concept of the fractal to show how the divisions in the city are indeed endlessly repeated, on all scales, in such a way that each part can stand for the whole and reproduces the exact same pattern of inequalities and processes of "invisibilization". It is indeed a process, as our gaze has become "fractal" too, adjusted so as not to see divisions and fault-lines, and Král advocates for us to learn to re-educate the eye to see those discontinuities and those invisible people again. The demonstration is compelling, even though in this last instance the use of the term "fractal" associated with the gaze can only be metaphorical and used a little freely. The conclusion is however very forceful too, going back to some of the issues raised in the introduction, in particular that of transparency, to suggest, using Umberto Eco's and Jean-Jacques Lecercle's notion of the "encyclopaedia" or shared set of representations, that the message of works of arts in our globalised world can only itself become fractal, received and interpreted in a myriad ways and necessarily creating degrees of misunderstanding.

6 Françoise Král's Social Invisibility and Diasporas in Anglophone Literature and Culture therefore does raise a number of essential issues, in an often compelling manner, even though one feels that the book may have benefited from a little more editing, and perhaps actually been a little longer to allow for all her ideas to be developed clearly (for instance her references to Levinas at the end of chapter 2 or to Marianne Hirsch and Deleuze and Guattari at the end of chapter 3) and more examples to be fully made use of at times given her ambitious scope. It remains an extremely fascinating and illuminating work whose call for the development of Invisibility studies no doubt will be heeded. 
INDEX

Mots-clés: diaspora, migration, mondialisation, visibilité, invisibilité, film, littérature, photographie, arts visuels, corps, ville

Keywords: diaspora, migration, globalisation, invisibility, visibility, film, literature, photography, visual arts, body, city

\section{AUTHORS}

\section{MATHILDE ROGEZ}

Maître de conférences

Université de Toulouse - Jean Jaurès

rogez@univ-tlse2.fr 